\title{
Exploring Linkages Between Sexuality and Rights to Tackle Poverty
}

\section{Henry Armas*}

\section{Introduction}

Why is it so difficult to talk about the sexuality and pleasure of the poor? In many development policies sexuality has been seen as an instrument for birth control, framing and limiting the terms of its perceived linkages with economic growth and poverty. AIDS issues have subsequently prompted the inclusion in this frame of sexuality and pleasure as 'risk factors' for people's health and well-being. Compounding this narrow focus, issues related to sexual rights have been seen and treated as additional to the 'real' and 'important matters' of housing, education, employment, etc. As a result, despite their circulation in development discourse, sexual rights have rarely been translated into specific and clear policies.

But what does something apparently not 'useful' like sexuality have to do with rights, citizenship and development? In this article, I will explore the linkages between sexual rights and the other socalled 'more important rights'. My main argument is not that sexual rights are not less important than rights to education, health or work, but that sexual rights are all these rights.

\section{Rights as development}

In the past, needs-based development approaches, along with a reluctance to frame sexuality and sexual pleasure as basic needs that have echoes in every aspect of life, obscured the connections between sexuality and development and disallowed their exploration. In recent years, the shift towards rightsbased approaches to development have helped to make these connections more evident: rights are a clear entry point for talking about sexuality in relation to many other domains of life, and the implications of these linkages for development.
Since the 1990s, rights-based approaches have became a crucial element in development discourse, policies and practices, continuing a previous process of work with international human rights, and extending it to engage with new actors and strategies for realising rights. According to Alza (n.d.), a rights-based approach constitutes above all a methodological tool that uses the discourse of constitutional and international theory of human rights, but goes further to incorporate a political dimension in the analysis.

For the United Nations system (United Nations 2003), a human rights-based approach implies that:

1 All programmes of development cooperation, policies and technical assistance should further the realisation of human rights as laid down in the Universal Declaration of Human Rights and other international human rights instruments.

2 Human rights standards contained in, and principles derived from, the Universal Declaration of Human Rights and other international human rights instruments guide all development cooperation and programming in all sectors and in all phases of the programming process.

3 Development cooperation contributes to the development of the capacities of 'duty-bearers' to meet their obligations and/or of 'rights-holders' to claim their rights.

Among donors, rights discourses vary according to different policies. For example, for the Swedish International Development Cooperation Agency (SIDA), a human rights approach means that people's economic, cultural, civil, political and social rights are 
considered in all parts of the development process. The aim is to foster the provision of human rights, to improve development cooperation and make it more efficient (SIDA 2001: 2).

Although there are many formulations of rightsbased approaches and practices, some common elements can be identified, including:

- An express linkage to rights

- An emphasis on accountability

- An emphasis on empowerment

- An emphasis on participation

- Special attention to non-discrimination and vulnerable groups. (Marks 2005: 102)

In the following section, the relationship between rights and sexuality will be developed using this framework.

\section{Rights and sexuality: making the links}

How can we go about exploring the links between rights-based approaches and sexuality? We will use the elements mentioned above to discover some connections:

- Sexual rights have a clear relationship with human rights. Principles of integrality and indivisibility allow talk about sexual rights, as interdependent with rights to health, housing, food or employment.

- Sexual rights allow people to demand accountability from power holders regarding the most personal and intimate relationships.

Sexual rights empower people not only regarding their decisions in their sexual lives, but also by generating self-esteem, a new perception of citizenship, and control over their own lives in other spaces such as health, education, employment, etc.

- Sexual rights increase the quality of participation both in terms of breadth (who participates) and depth (what they participate in).

Sexual rights visibilise people suffering discrimination, and vulnerable groups which have remained largely unnoticed by development agencies, governments and their programmes. Sexual rights are not only relevant to sexual and reproductive health projects, but are also an important element to take into account in broader strategies to tackle poverty.

Sexual rights have a variety of definitions, constantly contested by a variety of noisy political and cultural agendas. The Platform for Action from the 1995 Beijing Conference on Women made progress on establishing sexual rights in the following terms:

97. The human rights of women include their right to have control over and decide freely and responsibly on matters related to their sexuality, including sexual and reproductive health, free of coercion, discrimination and violence. Equal relationships between women and men in matters of sexual relations and reproduction, including full respect for the integrity of the person, require mutual respect, consent and shared responsibility for sexual behaviour and its consequences.

Sweden has used this paragraph as the applicable definition of women's sexual rights (Ministry for Foreign Affairs, Sweden 2006: 7). Furthermore, Sweden considers that sexual rights include already recognised human rights, for example the right to private life (UN Universal Declaration of Human Rights, Article 16) and personal safety (UN Convention on the Elimination of all Forms of Racial Discrimination, Article 5b). It is a fundamental principle of human rights that one individual's rights must not encroach on those of another. In sexual relations or matters concerning sexuality and reproduction, personal and physical integrity must be respected. In light of this, the Swedish Government defines sexual rights as meaning that all people, irrespective of sex, age, ethnicity, disability, gender identity or sexual orientation, have a right to their own body and sexuality. In addition to this, the Swedish International Development Cooperation Agency (SIDA) also takes into account the general human rights principle of non-discrimination on sexual or other grounds, such as sexual orientation or gender identity.

According to the working definition for sexual rights provided by the World Health Organization (WHO), they embrace human rights that are already recognised in national laws, international human rights documents and other consensus statements. They include the rights of all persons, free of coercion, discrimination and violence, to: 
- The highest attainable standard of sexual health, including access to sexual and reproductive healthcare services

- Seek, receive and impart information related to sexuality

- Sexuality education

- Respect for bodily integrity

- Choose their partner

- Decide to be sexually active or not

- Consensual sexual relations

- Consensual marriage

- Decide whether or not, and when, to have children

- Pursue a satisfying, safe and pleasurable sexual life. (WHO 2006)

\section{Beyond sexual rights}

Perhaps the most productive linkage between rights and sexuality is the principle of the indivisibility of human rights. The World Conference on Human Rights in Vienna in 1993 stated that all human rights are universal, indivisible, interdependent and interrelated. The international community must treat different human rights with the same emphasis.

These principles are based on the undeniable fact that violations of certain rights affect others.

Principles of integrality, indivisibility and interdependence lead us to approach sexual rights as interrelated with rights to education, health, work, political participation, mobility, and as having effects on migration, food, housing, etc.

Despite the theoretical consensus on integrality, policymakers have rarely attempted to take on board the numerous real and practical linkages between sexual and other rights. Some of these relations are described below.

\subsection{In health}

Female genital mutilation (FGM) is an attempt to eliminate sexual pleasure. But there are also other non-physical mutilations of women's desire including shame, guilt feelings and fixed assigned roles. These symbolic mutilations affect many other people, women or not, sexual dissidents or not, and have a direct effect on people's mental health and wellbeing. Heteronormativity affects the health of many men and women and therefore influences their inclusion in economic life. The trajectory of HIV/AIDS provides a good example of this. Violence and exclusion experienced by many people due to heteronormativity discourages them from having safer sex. Men who have sex with men (MSM) are the most affected group. For example, research in Thailand shows HIV/AIDS prevalence rates of up to 16 per cent among gay men, compared with approximately 1 per cent in the general adult population (Samelius and Wägberg 2005: 24). At the same time, unequal treatment for same sex couples limits their access to health insurance.

On the other hand, exclusion in the workplace and in social and family environments can create vulnerability to physical abuse and psychological aggression. In both cases, people's health is at risk. Depression and stress suffered by lesbian, gay, bisexual and transgender (LGBT) people who have to hide their sexual orientation is also an important element to consider.

\subsection{In education}

There is not enough research concerned with how sexual rights violations affect education. According to Andil Gosine (2005: 7-8), one study in Bangladesh in 2002 showed that 'feminine' boys were more likely to be bullied in school, drop out and end up in poverty:

The 124 men interviewed for the study named many hardships experienced which were linked to their sexual practices and identities ... Nearly half of the respondents (48 per cent) stated that fellow students or teachers had harassed them in school or college because they were effeminate, and most of them believe that their study habits suffered as a result ... 'It is clear from the in-depth interviews as well as from the [focus group discussions] that economic deprivation was a result arising from harassment during education', the study stated. (Naz Foundation International 2002, cited in Gosine 2005: 7-8)

Teenage mothers also often have to abandon school due to social pressure or formal sanctions, contributing to a vicious circle of teenage pregnancy, low education and poverty. Young women expelled from school for pregnancy rarely return: a 1993 study in Jamaica found that 32 per cent of young women who had ever been pregnant became pregnant for the first time while still in school, and that almost 60 per cent of these pregnancies occurred before the fourth year of secondary school. Of these young women, only 16 per cent returned to school after 
the birth of their first child. Some 86 per cent of those who became pregnant while in primary school never advanced to secondary school (Morris et al. 1995, cited in Advocates for Youth 2006).

An issue related to this is sexual education. If governments do not incorporate sexuality as an important element in their national curricula, people (and especially teenagers and young people) have less opportunity to take informed decisions regarding parenthood, sexual initiation, HIV prevention, etc. Sexual education creates opportunities to empower citizens and to give people the capacity to make decisions about their own lives and bodies. Lack of it impoverishes people.

\subsection{In work}

Heteronormativity creates limitations for LGBT people in their labour rights. There is a problem not only at the moment of access, but also for job stability. This problem is particularly acute in certain fields, such as education or the armed forces.

According to an exploratory survey on employment discrimination experienced by lesbians in Colombia (ADEIM-Simbiosis et al. 2006: 76-8), 14 per cent of interviewees had been fired from a job at least once because of their sexual preference, and 16 per cent had been denied employment for the same reason. A total of 30 per cent of the interviewees had faced severe forms of employment discrimination based on sexual orientation; 26 per cent of those surveyed said they had experienced mistreatment at their job, and 36 per cent said they knew of another lesbian who had been mistreated. For transgender people, access to employment is more difficult still. As a consequence, many of them are forced into prostitution.

Violations of sexual rights create a negative cycle of limited opportunities in education which compound limited opportunities in employment caused by discrimination. Together these result in weaker capacities and poverty.

\subsection{In migration}

Migration and its economic effects have a direct relationship with sexual rights. People discriminated against in employment and education have extra reasons for seeking economic security through national and international migration. Other powerful push factors are the limited possibilities for LGBT people to love, have families or develop an identity or a particular sexual life in their original countries: in around 70 countries in the world, homosexuality is a crime.

According to Samelius and Wägberg (2005: 22), Sudan, Saudi Arabia, Afghanistan, Pakistan, Iran and Mauritania have the legal possibility of issuing death sentences for consenting homosexual acts. Members of organisations working openly with advocacy for LGBT rights are at great risk of imprisonment for promoting illegal activities in some countries.

Conviction may mean imprisonment for up to 10 years, forced hard labour, heavy fines or corporal punishment.

The legal status of same sex couples is different from heterosexual couples in some countries, resulting in a range of issues for LGBT relationships.

Heteronormative definitions of the family frame policies allowing entry to legal migrants' families; the legal status available to migrants through heterosexual marriage is rarely available through LGBT relationships. This has economic consequences: there are more barriers for LGBT migrants, and they are more likely to be confined to illegal status and social exclusion.

Patriarchy and male chauvinism in relation to sexual rights have also created reasons for (heterosexual) women to migrate: the violence enshrined in FGM or social pressures and exclusion around women's sexual reputation, for instance, can be strong push factors for internal and international migration.

\subsection{Other rights}

Discrimination and prejudice regarding sexuality also affect people's right to political participation. A case in point is that of Lourdes Flores, one of the most popular candidates for President during the last electoral process in Peru in 2006. She was the first woman in Peru with real possibilities of winning the election, but she was attacked by other candidates on the grounds of not being a mother or married: her lack of maternal sensibility apparently demonstrated by this state of affairs made her an unsuitable person for running the country. It is interesting that it was not being a woman that was at issue here, but the sexual rights that she had claimed in remaining single and childless at the age of 45 . As in other countries, many voters made their decisions based on prejudice and not on government proposals. 
The right to food can also be affected by sexual rights violations. Amartya Sen has reflected on the relationship between freedom and the success of the pursuit of food for all. According to him:

Insofar as public policy to combat hunger and starvation - including rapid intervention against threatening famines - may depend on the existence and efficiency of political pressure groups to induce governments to act, political freedom too may have a close connection with the distribution of relief and food to vulnerable groups ... Freedom to make profits is not the only freedom the causal influence of which would have to be considered. Thus, what may superficially appear to be rather remote connections between food and freedom can be seen to be, in fact, central in importance and extremely rich in the variety of influences involved, operating in the two respective directions, viz., from food to freedom, and from freedom to food. (Sen 1987: 2)

Normative assumptions about the correct organisation of sexuality have often limited women's rights to the fruits of development. I would like to mention a personal experience here of when I travelled to an Andean rural community in the south of Ayacucho, Peru, in 2001, leading a university group to provide assistance to people affected by an earthquake. Distributions of food and medicine, at the request of our partner organisation, were made according to lists provided by the leaders of these villages. The leaders decided to distribute the aid by families, and decided that single mothers and their children did not count as families. Only the fathers of these women were considered for aid, and would decide how to distribute the resources within their extended families.

\section{Notes}

* This article was elaborated with the invaluable contribution and support of Carolyn Williams, Gustavo Zambrano Chávez, Margarita Díaz Picasso, Susan Jolly, Andrea Cornwall and Ulrica Risso Engblom. I am grateful for their comments, submitted documents, conversations, insights, reflections and friendship.

\section{Final reflections}

We have seen that sexual rights violations can affect health, employment, education, migration and political participation. Taking these violations seriously calls for action on several fronts. First of all, there is an urgent need to document and make more visible both the connections highlighted in this article, and the violations of human rights that arise in relation to sexuality. Where this research and documentation would be especially valuable is in quantifying the economic impact of sexual rights violations, and highlighting the economic as well as human costs of denying people access to these rights. Second, greater involvement needs to be sought from international organisations working on education, labour, migration, and poverty reduction, such as the International Labour Organization (ILO), the United Nations World Food Programme (WFP) and the United Nations High Commissioner for Human Rights. Issues of sexuality arise in relation to many dimensions of their work, whether on health, education, food, freedom of opinion and expression, housing, migration or poverty. These organisations should incorporate sexuality and sexual rights directly into their work, recognising its implications for all that they strive to do.

The links are clear. Sexual rights are human rights and pretending that the problem does not exist will only weaken the wider strategy of advancing human rights. If these linkages remain invisible, the consequences go beyond the many human rights violations that will remain in the shadows. Without a recognition of the implications of sexuality for all that constitutes 'development', there is little doubt that efforts to improve the security and well-being of people living in poverty will be less able to make a genuine, lasting difference. 


\section{References}

ADEIM-Simbiosis, Artemisa, Cattrachas, Criola, IGLHRC and Red Nosotras LBT (2006) 'Unnatural', 'Unsuitable', Unemployed! Lesbians and Workplace Discrimination in Bolivia, Brazil, Colombia, Honduras and Mexico, Buenos Aires: International Gay and Lesbian Human Rights Commission (IGLHRC)

Advocates for Youth (2006) The Impact of Early Pregnancy and Childbearing on Adolescent Mothers and Their Children in Latin America and the Caribbean, www.advocatesforyouth.org/ publications/factsheet/fsimpact.htm (accessed 15 March 2006)

Alza Barco, Carlos (no date) 'Enfoque de Derechos en los Servicios Públicos: La Defensoría del Pueblo y el Derecho Humano al Agua' (unpublished)

Gosine, A. (2005) Sex for Pleasure, Rights to Participation, and Alternatives to AIDS: Placing Sexual Minorities and/or Dissidents in Development, IDS Working Paper 228, Brighton: IDS

Marks, S.P. (2005) 'Human Rights in Development', in S. Gruskin, M. Grodin, G. Annas and S. Marks (eds), Perspectives on Health and Human Rights, New York: Routledge

Ministry for Foreign Affairs, Sweden (2006) Sweden's International Policy on Sexual and Reproductive Health and Rights, Stockholm: Ministry for Foreign Affairs

Morris, L., Sedivy, V., Friedman, J.S. and McFarlane, C.P. (1995) Contraceptive Prevalence Survey, Jamaica 1993, Vol 4, Sexual Behaviour and
Contraceptive Use Among Young Adults, Atlanta, GA: US Department of Health and Human Services and Center for Disease Control and Prevention Naz Foundation International (2002) Social Justice, Human Rights and MSM, Naz Briefing Paper 7, London: Naz Foundation International Samelius, L. and Wägberg, E. (2005) 'Sexual Orientation and Gender Identity Issues in Development', A Study of Swedish Policy and Administration of Lesbian, Gay, Bisexual and Transgender Issues in International Development Cooperation, Stockholm: Swedish International Development Cooperation Agency (SIDA)

Sen, A. (1987) Food and Freedom, Sir John Crawford Memorial Lecture, Washington DC

SIDA (2001) A Democracy and Human Rights Based Approach to Development Cooperation, Stockholm: Suedish International Development Cooperation Agency (SIDA)

United Nations (2003) Statement on a Common Understanding of a Human Rights-Based Approach to Development Cooperation, as Agreed at the Stamford Workshop and Endorsed by the UNDG Programme Group, http://portal.unesco.org/shs/ en/ev.php-URL_ID=7947\&URL_DO=DO_TOPIC\& URL_SECTION=201.html, Paris: United Nations (accessed 15 March 2006)

World Health Organization (WHO) (2006) Gender and Reproductive Rights, www.who.int/ reproductive-health/gender/sexual_health.html (accessed 15 March 2006) 